\title{
Medicolegal
}

\section{Doctor sues BBC and two other doctors for libel}

\author{
CLARE DYER
}

A libel action by a private practice general practitioner against the BBC, which could run till after Christmas, entered its fourth week in the High Court this week. Dr Sidney Gee, who has a special interest in the problems of obesity, is suing for damages over criticisms of his treatment broadcast on the $\mathrm{BBC}$ programme That's Life. Apart from the BBC, there are five other defendants: Esther Rantzen, the programme's chief presenter, Gavin Campbell, assistant presenter, and Gordon Watts, editor, Dr Clemency Mitchell, a general practitioner who practises at Binfield in Berkshire, and Dr Roger Blackwood, consultant physician at the King Edward Hospital, Windsor.

The claims arise from a programme broadcast on 26 June 1983 which featured the case of Mrs Elizabeth Day, a patient of Dr Gee. The programme alleged that Dr Gee had put Mrs Day's life in danger by prescribing unsuitable and dangerous drugs, without identifying the medicines, and that he was guilty of a breach of ethics in failing to inform Mrs Day's general practitioner, Dr Mitchell, of her treatment.

Included in the broadcast were a quote from Dr Blackwood criticising Dr Gee's treatment of Mrs Day and extracts from his and Dr Mitchell's letters to Dr Gee. The presenters finished up: "Mrs Day's doctors have told us they are going to report this case to the General Medical Council, because after all the GMC have power to strike off a doctor for serious professional misconduct, for neglect or disregard of personal responsibilities to patients for their care and treatment like, for example, prescribing drugs for a patient which could have killed her." (The hearing of the complaint to the GMC has been postponed to allow the libel claim to be disposed of first. ${ }^{1}$ )

The words used in the programme, says Dr Gee in his statement of claim, meant and were understood to mean that he was "an unscrupulous profiteering quack who had nearly killed Elizabeth Day by illegally prescribing dangerous amounts of dangerous drugs for her to take, and who was guilty of criminal negligence and unfit to remain in medical practice."

The BBC's main defence is justification-in other words, that the allegations are true. They also contend that the words used were fair comment on a matter of public interest.

The trial opened on 23 October with Dr Gee's leading counsel, Michael Beloff, QC, outlining his client's case for Mr Justice Croom-Johnson and the jury. At the conclusion of the case, counsel said, the jury might consider Dr Gee's treatment to be untypical in British local terms, though standard in the United States. But a doctor like Dr Gee could not be pilloried on a prime time programme just because his methods were more likely to be paralleled in Boston than in Berkshire.

Dr Mitchell and Dr Blackwood, he said, had divulged their private correspondence to the $\mathrm{BBC}$, though they could reasonably have expected that the BBC would approach the matter not with care, but with haste, and without any relevant experience. Mrs Day had come into contact with the BBC no earlier than 20 June.

London NW1

CLARE DYER, BA, BLS, solicitor and legal journalist
That left a maximum of six days in which the BBC saw fit to take steps to destroy a reputation built up over more than 30 years. It was hard to imagine circumstances in which the libel could have been more widely publicised. Mr Beloff concluded his opening speech by asking the jury to award his client a substantial sum in damages.

In his examination in chief, Dr Gee told the jury he practised privately at Victoria House, 19 Victoria Street, Rochester, Kent, spending one day a week at 67 Harley Street. He said he refused to take patients who were under active treatment by other doctorsfor instance, taking tablets for high blood pressure.

When Mrs Day first came to see him in Harley Street in October 1982 , she was not asked for a letter of referral from her general practitioner. This was necessary only if a patient consulted a specialist, Dr Gee explained. He was not a specialist but a general practitioner with a special interest in obesity.

With Mrs Day, as with all new patients, he would have taken a normal medical history. She had not mentioned that she was currently receiving any medical treatment or taking any medicine. There was nothing in her history which contraindicated his normal regimen. He also carried out a routine examination. Her blood pressure and pulse rates were within normal limits.

He spoke to Mrs Day about diet and exercise, he continued, gave her a vitamin B injection, and handed her a diet sheet and an envelope containing three weeks' supply of tablets: $150 \mathrm{mg}$ of caffeine citrate and $30 \mathrm{mg}$ phenolphthalein, in combination, to be taken once a day; $0.6 \mathrm{mg}$ atropine sulphate twice a day; $125 \mathrm{mg}$ thyroid extract twice a day; and $5 \mathrm{mg}$ dexamphetamine sulphate once a day.

The caffeine citrate raises the metabolic rate by about $10 \%$ for about two hours, Dr Gee explained. The phenolphthalein counteracts constipation accompanying a low residue diet. The atropine sulphate dries up the gastric and salivary secretions making the appetite less intense. Thyroid extract is prescribed not for the thyroxine it contains, but for the tri-iodothyronine. When people diet tri-iodothyronine concentrations fall, producing a resistance to losing weight.

On her eighth and ninth visits, in April and May 1983, Mrs Day complained of a "rapid pulse." Dr Gee said he found her pulse rate to be within normal limits but told her on the eighth visit to reduce the thyroid extract and on the final visit to discontinue it.

Around 18 May, Dr Gee continued, he received a letter from Dr Mitchell informing him that Mrs Day had been to see her and had "been noted to have a resting pulse rate of 120 or more on several recent occasions by several different people." The letter went on: "I note there are only two indications for the use of [Dexedrine] in the British National Formulary: these are narcolepsy and hyperkinesis in children." She also mentioned the possibility of a complaint to the ethical committee of the BMA.

Dr Gee also received a letter from Dr Blackwood telling him that Mrs Day was suffering from chest pains, had a pulse rate of 140, was unable to sleep, and was experiencing breathlessness, diarrhoea, and general agitation. Further letters from Dr Mitchel and Dr Blackwood complained that he had still not identified the tablets supplied to Mrs Day. But up to that time, he said, neither 
had actually asked for that information. He replied to $\mathrm{Dr}$ Blackwood's request, though he made some slight errors through stress and through failing to look up Mrs Day's records.

On 22 June-four days before the That's Life broadcast-a new "patient" calling himself Leslie Kent consulted him, Dr Gee went on. It was only on the following day, when the BBC having made a fake appointment for a consultation, staged a confrontation with Dr Gee in the presence of his nurse and two patients that he realised that Leslie Kent was a BBC employee. The next day, Friday, a letter arrived from Gavin Campbell, assistant presenter of That's Life, posing nine questions about Dr Gee's treatment and asking for an answer over the telephone later that morning. $\mathrm{He}$ could not answer the questions in that time, said Dr Gee, though he offered to reply if given more time. The BBC's response was that the programme scheduled for 26 June was the last of the series, and he received a further letter on Saturday giving him until noon on Sunday, the day of the broadcast, to answer the questions. He was unable to do so in such a short time, but he supplied the BBC with a Department of Health report and two scientific articles which he hoped would make them realise that there might be another side to the story.

The final part of Dr Gee's evidence dealt with his treatment of other patients whose cases the BBC will refer to in their evidence. He concluded by describing the impact of the broadcast on him: "a feeling of shame and inadequacy."

Brahams D. Doctor's action for libel in High Court to be heard before GMC proceedings relating to the same matters. Lancet 1984 ;ii:1050-

\section{Crown immunity protects service surgeons}

BY OUR LEGAL CORRESPONDENT

An ex-serviceman who wished to sue the Ministry of Defence and a Royal Air Force surgeon for damages for alleged negligence has failed in his efforts to challenge the legality of the defence of Crown immunity relied on by the proposed defendants.

Mr Kenneth Pinder, aged 46, alleged that while he was serving as a corporal in the RAF he contracted multiple liver abscesses as a result of a severe infection after an ulcer operation performed on him by an RAF surgeon in 1976, at RAF Hospital, Cosford (since demolished). He was invalided out of the service and now receives a pension of about $£ 375$ a month. The payment of the pension does not imply any finding or admission of negligence. Mr Pinder's lawyers valued his claim for damages at about $£ 100000$.

In response to a claim for damages the Ministry relied on section 10 of the Crown Proceedings Act, 1947. Section 10 provides that where death or personal injury is caused by a member of the armed forces while on duty to another member of the armed forces neither the Crown nor the serviceman who caused the injury or death shall be liable in tort provided two conditions are satisfied. Those conditions are that, firstly, the person injured or killed was either on duty or was on any land, premises, ship, or vehicle being used for the purposes of the armed forces of the Crown and, secondly, that the Minister of Pensions certifies that the death or injury will be treated as attributable to service for pension purposes.

Mr Pinder's lawyers argued that, since his injuries were not received while on active service or in training, section 10 of the Act was a denial of his rights under the European Convention of Human Rights. Cases concerning the convention are heard by the European Court of Human Rights, but the court has jurisdiction only over cases brought before it either by a state which is a party to the convention or by the European Commission of Human Rights. The European Commission declared Mr Pinder's claim inadmissible.

The immunity granted by the statute does none the less give rise to some anomalies. The immunity of the actual alleged wrongdoer has been criticised in principle, but without it there would probably have been a revival of the pre-1947 practice of suing the individual in the hope that the Crown would stand behind him. In the present case a surgeon would have been a sufficiently tempting target whether or not he was insured with a protection society.

Service surgeons certainly ought to be insured because their immunity from suit is not universal, since it arises only where the two qualifying conditions are both satisfied. They would not be satisfied where a civilian ex-serviceman is treated in a ser- vice hospital. Even serving servicemen may be treated for non-pensionable conditions, such as injuries from motor accidents while on leave.

The immunity does not extend to civilians. So if a service surgeon were assisted by a civilian surgeon and they injured their patient by their joint negligence the patient might sue the civilian surgeon alone and recover the whole of his damages from him. If the immunity applied to the service surgeon the civilian would be unable to obtain any contribution from him or the Crown. Equally, patient could sue a supplier of contaminated drugs or defective equipment if he could prove fault, jus as a soldier might sue the negligent manufacture of a rifle which exploded on firing even in battle conditions (though in the latter case the difficulties of proof might be more than usually burdensome)

In submissions to the commission, it was argued on behalf of the Crown that pensions were at least as advantageous to servicemen as the right to sue for damages since they were tax free, reviewed regularly, and payable without proof of negligence. That claim has been disputed so far as concerns the financial value of the pension by comparison with damages. Moreover, it has happened on occasion that no pension is paid despite the granting of the

\section{Mental disorder and prison}

\section{BY OUR LEGAL CORRESPONDENT}

Yet another case has been reported of a mentally disordered person being sent to prison because there is no other institution willing to receive her.

At Aylesbury Crown Court Judge Verney sentenced a severely mentally disordered woman aged 22 to life imprisonment for arson. ${ }^{1}$ Neither Buckinghamshire Social Services nor Oxford Regional Health Authority could provide facilities for her treatment.

The woman had previously come before the courts in 1981 accused of arson of a printing work causing $£ 100000$ worth of damage. On that oc casion the Department of Health had refused her a place in a special hospital, and no other appropriate facilities were available in the county or region. But Milton Keynes Health Authority had paid about $£ 50000$ for her to receive treatment at St Andrews Psychiatric Hospital, Northampton (where there are no secure facilities) under the terms of a thre year probation order. In June this year St Andrews discharged her and within two weeks she caused $£ 700$ worth of damage to a car by scratching graffit on it. While in a remand hostel she set a wastepaper bin alight and was severely disruptive. St Andrew was now unwilling to readmit her, believing she
Minister's certificate. In 1955 a $\mathrm{Z}$ reservist was killed on exercise at Bulford, the Minister granted his certificate, but a pension was refused to his parents because they did not come within the pen sionable category (that is, they were deemed not to be "in pecuniary need"). The parents were still denied the right to sue the War Office. ${ }^{2}$

Since the decision by the European Commission in favour of the British government, the English High Court has upheld a further claim to Crown immunity in a case where complaints of medical negligence were made against an army doctor. ${ }^{3}$

A serviceman received a blow on the head while engaged in horseplay on army property but not on duty. In an action brought by his father it was alleged that he was not seen by a doctor for an hour and a half, and when the doctor decided that he did not require treatment he was returned to the guardroom. Shortly afterwards he was sent back to the medical centre but was not seen by a doctor for more than an hour. He was then sent to a civilian hospital with inadequate information and died. No evidence was called in support of these allegations because the defence of Crown immunity was tried as a preliminary issue of law and was decided in favour of the Crown.

Terence Shaw. Servicemen's right to sue Ministry is rejected. Daily Telegraph Oct 23 1984: 13 (cols 7-8).

3 Anonymous. Crown Immunity. The Times Oct 30 1984: 12 (cols $5-6$ ).

would not respond to treatment, and in any case no funds were available to pay for her care there. In default of other appropriate facilities the judge reluctantly imposed a life sentence to protect the public. An appeal is proposed in the hope that the Court of Appeal can use its influence to obtain suitable facilities.

The governing legislation (now the Mental Health Act, 1983 section 37 ) requires that the court shall not make a hospital order after a criminal conviction unless the court is satisfied by evidence that arrangements have been made for the admission of the defendant to hospital within 28 days in the event of an order being made. The options open to the court may therefore be limited if facilities are not made available.

Large numbers of prisoners are known to be mentally ill, and the judges are known to be unhappy about this. Last year Lord Justice Lawton said, "Putting people who are severely mentally ill into prison is a form of cruelty. Not only that, but imposes a great strain on the prison staff." ${ }^{2}$ In an earlier appeal concerning a psychopathic petty offender, Lord Justice Lawton said, "Her Majesty's courts are not dustbins into which the 